\title{
Aplikasi Penerimaan Pemasukan Dan Pengeluaran Dana Keuangan Berbasis Website Pada CV. Berkah Jaya
}

\author{
Ahmad Fauzi ${ }^{1}$, Nurlaelatul Maulida ${ }^{2}$, Riki Supriyadi ${ }^{3}$, Hiya Natalissifa ${ }^{4}$, Sri Diantika ${ }^{5}$ \\ Universitas Bina Sarana Informatika ${ }^{1,2,4,5}$, Universitas Nusa Mandiri ${ }^{3}$ \\ ahmad.fzx@bsi.ac.id ${ }^{1}$, nurlaelatul.nlt@bsi.ac.id ${ }^{2}$, riki.rsd@nusamandiri.ac.id ${ }^{3}$, \\ hiya.hys@bsi.ac.id ${ }^{4}, \underline{s r i . s z d @ b s i . a c . i d ~}$
}

\begin{abstract}
Abstrak CV. Berkah Jaya merupakan perusahaan milik swasta yang bernaung dalam usaha sebagai supplier toko buku dan alat peraga ke berbagai tempat. Sebagai supplier buku dan alat peraga CV. Berkah Jaya memiliki cukup banyak data yang belum terorganisir dengan baik, terutama dalam bidang pencatatan penerimaan dan pengeluaran dana keuangan. Sistem pencatatan data pada CV. Berkah Jaya saat ini masih dilakukan secara konvensional meskipun sudah menggunakan microsoft excel sebagai program yang membantu dalam pencatatan, seringkali menjadi kurang efektif dan tidak efisien sehingga menimbulkan hambatan karena dibuttuhkan waktu yang agak lama dalam memproses data. Data pemasukan dan pengeluaran dana keuangan akan mudah dimanipulasi dari pihak yang tidak bisa bertanggung jawab jika masih menggunakan sistem pencatatan yang manual. Adanya sistem komputer akan sangat membantu perusahaan dalam pemecahan masalah dalam hal pengelohan data keuangan. Penggunaan komputer juga dapat dijadikan alat untuk mencapai tujuan dan mencari kemudahan dalam melakukan suatu proses pekerjaan, terutama yang melibatkan banyak data dalam hal ini mengenai data transaksi yang mencakup data pemasukan dan pengeluaran dana keuangan perusahaan. Dengan sistem komputerisasi keuangan ini, dapat mempermudah perusahaan dalam melakuan proses pengolahan data keuangan dan laporan.
\end{abstract}

Kata Kunci : Sistem Informasi Akuntansi, Pengolahan Data Keuangan, Website

\begin{abstract}
CV.Berkah Jaya is a private company which are protected by supplier effort as the bookstore and props to different places. As a supplier books and props CV. Berkah Jaya have enough data not been well organized, especially in the field of recording data income and expenditures financial funds. Data recording system on CV. Berkah Jaya is currently still done manually even though it already uses Microsoft Excel as a program that helps in recording, often becomes less effective and inefficient, causing obstacles because it takes a long time in processing data. Data on the income and expenditure of financial funds will be easily manipulated by irresponsible parties if they still use a manual recording system. The existence of computer systems will greatly help companies in solving problems in terms of financial data collection. The use of computers can also used as a means to achieve the goals and ease to find work process, work especially involving a lot of data in this transaction data on which includes financial data income and expenditures of corporate financial funds. With this financial computerized system, it can make it easier for corporate to process financial data and reports.
\end{abstract}

Keywords: Accounting Information Systems, Data Processing Finance, Website

\section{PENDAHULUAN}

Di era teknologi seperti saat ini, bidang usaha dihadapkan pada situasi dan kondisi persaingan bidang usaha yang semakin ketat, tuntutan perusahaan untuk menjalankan usahanya dengan lebih baik dan efisien. Hal ini sejalan dengan tingginya tingkat persaingan, perekonomian, perkembangan dan kemajuan bidang teknologi maka dari itu peranan informasi menjadi sangat penting demi kemajuan perusahaan. "Informasi dari perusahaan, terutama dalam informasi keuangan dibutuhkan oleh berbagai macam pihak-pihak yang berkepentingan. Pihakpihak di luar perusahaan, misalnya seperti kreditur, kantor pajak, calon investor dan lainnya memerlukan informasi ini dalam kaitannya dengan kepentingan yang dibutuhkan mereka. disamping itu, pihak intern yaitu manajemen juga memerlukan informasi keuangan untuk mengetahui, mengawasi, dan mengambil keputusankeputusan untuk menjalankan perusahaan untuk memenuhi kebutuhan informasi baik bagi pihak luar maupun dalam perusahaan, maka perlu disusun suatu sistem akuntansi" (Akuntansi \& Ekonomi, 2016).

Kemajuan teknologi informasi dan komputer merupakan salah satu yang paling pesat dibandingkan bidang lainnya. Pertumbuhan eknoogi informasi ini semakin meningkat dari tahun ke tahun, hal ini bisa di lihat dari penggunaan komputer di segala aspek, baik itu perusahaan jasa, perdagangan, maupun 
industri, mulai dari perusahaan dengan skala kecil, maupun besar, hingga multi nasional (Lisnawanty \& Kurniawan, 2019).

Dengan demikian pengendalian intern merupakan hal yang sangat penting dimiiki oleh pimpinan perusahaan dalam rangka memantau dan mengambil kebijakan-kebijakan yang akan ditetapkan dan memberikan keyakinan kepadanya bahwasannya tujuan perusahaan akan dapat dicapai. Dimana Pengendalian Intern juga dapat melindungi aset perusahaan dari pencurian, kecurangan, penyalahgunaan, atau kesalahan penempatan serta dapat mempertinggi kebenaran dan keakuratan pencatatan akuntansinya. Untuk itu sistem pengendalian intern harus secara terus menerus dipantau dan dinilai (Danial et al., 2019).

Setiap perusahaan baik itu milik swasta maupun milik pemerintah, yang bergerak dalam bidang perdagangan, jasa, industri, dan sebagainya pasti menginginkan kegiatan operasinya berjalan lancar sesuai dengan sistem dan prosedur yang telah ditetapkan sebelumnya oleh pemilik perusahaan dengan dibantu oleh manajer puncak untuk mencapai tujuan dari perusahaan tersebut.

Pada kenyatannya kegiatan operasi perusahaan tidaklah selalu berjalan dengan lancar tanpa adanya hambatan, baik hambatan yang berasal dari internal perusahaan itu sendiri maupun hambatan yang berasal dari luar perusahaan. Oleh karena itu, perusahaan perlu menerapkan metode pengelolaan yang memadai terhadap aktivitas yang dilakukan perusahaan tersebut. Dengan metode pengelolaan yang baik, pelaksanaan operasi perusahaan dapat tercapai secara efektif dan efisien. Metode pengelolaan yang biasanya diterapkan di perusahaan adalah adanya Sistem Pengendalian Intern. Pengendalian Intern ini diperlukan dalam segala bidang, baik terhadap aktivitas operasi perusahaan maupun untuk kebijakan-kebijakan yang harus dilaksanakan oleh para pegawai perusahaan tersebut.

Dengan permasalahan yang sudah dijelaskan di atas, maka perlu adanya implementasi atau penerapan dalam menggunakan aplikasi yang terdapat sistem untuk mengumpulkan dan memproses data yang terdapat proses transaksi dan laporan keuangan. Maka dari itu, penelitian ini dibuat dengan tujuan untuk memberikan solusi terhadap pengelolaan dana keuangan berupa Aplikasi Penerimaan Pemasukan Dan Pengeluaran Dana Keuangan Berbasis Website Pada CV. Berkah Jaya, agar dapat memproses data-data transaksi yang ada dijadikan laporan keuangan dengan cepat dan akurat.

\section{METODOLOGI PENELITIAN}

Metode penelitian adalah suatu langkah yang harus dimiliki dan diterapkan peneliti mengumpulkan informasi atau data serta melakukan pengkajian pada data yang telah di berikan. Perkembangan perangkat lunak ini dapat diartikan juga sebagai proses untuk membuat suatu perangkat lunak baru dengan tuhuan untuk menggantikan perangkat lunak lama secara keseluruhan atau memperbaiki perangkat lunak yang sudah ada. Agar lebih efisien dan tepat dalam membuat solusi dan mengembangkan perangkat lunak, juga hasilnya mudah untuk dikembangkan dan dipelihara, maka dari itu pengembangan perangkat lunak membutuhkan suatu metodologi yang khusus. Metodologi pengembangan perangkat lunak merupakan suatu proses pengorganisasian kumpulan metode dan konvensi notasi yang telah diartikan untuk mengembangkan perangkat lunak.

\section{Metode Pengumpulan Data}

Metode yang digunakan dalam pembuatan penelitian ini adalah deskriptif, penelitian deskriptif digunakan untuk memberikan gambaran yang lebih lengkap mengenai kejadian, baik kejadian yang sedang berlangsung saat ini, maupun kejadian yang sudah terjadi sebelumnya.

a. Observasi (Observation)

Metode Observasi yang dilakukan penulis pada Tugas Akhir ini adalah melakukan pengamatan secara langsung dan pencatatan yang sistematis untuk pengolahan data yang diperlukan(Ningtiyas, 2017).

b. Wawancara (Interview)

Mendapatkan informasi atau data yang diinginkan dan juga melakukan tanya jawab antar muka secara langsung ke beberapa staff di CV.Berkah Jaya.

c. Studi Pustaka (Library Research)

Untuk studi pustaka penulis juga banyak sekali terbantu dalam mendapatkan data dari berbagai buku dan jurnal yang bisa tersedia di perpustakaan dan internet yang bisa diangkat penulis sebagai pedoman dan referensi.

\section{Metode Pengembangan Software}

Dalam pembuatan aplikasi ini penulis menggunakan metode Waterfall SDLC (Software Development Life Cycle), metode Waterfall SDLC ini menurut sukamto dalam (Apriliah et al., 2018) adalah proses mengembangkan atau mengubah suatu sistem perangkat lunak menggunakan model-model dan metodologi untuk 
mengembangkan sistem-sistem perangkat lunak sebelumnya (berdasarkan best practise atau cara-cara yang sudah teruji baik).

\section{a. Analisa Kebutuhan Software}

Tahapan ini merupakan analisa terhadap kebutuhan sistem yang dilakukan secara intensif untuk menspesifikasikan menu-menu yang diperlukan oleh pihak perusahan dalam mengelola pemasukan dan pengeluaran dana keuangan seperti data penggunaan, data pegawai, data customer, data pemasukan keuangan, data pengeluaran keuangan, dan laporan keuangan.

b. Desain

Tahapan dalam proses desain pada penelitian ini meliputi rancangan sistem dengan menggunakan rancangan database menggunakan Use Case Diagram, Activity Diagram, Entity Relationship Diagram (ERD), Logical Record Structure (LRS), Sequence Diagram, Class Diagram, dan User Interface (UI).

\section{c. Code Generation}

Code Generation adalah proses dimana compiler's generator kode mengkonversi beberapa perwakilan intermedit dari kode sumber menjadi bentuk (misalnya, kode mesin) yang dapat dengan mudah dijalankan oleh mesin. Dan adapun bahasa pemrograman yang digunakan penulis yaitu menggunakan bahasa pemprograman PHP, Javascript, dan sebagai databasenya yaitu MySQL(simatupang julianto, 2019).

\section{d. Pengujian / Testing}

Pengujian berfokus pada perangkat lunak logic dan fungsional serta memastikan semua bagian sudah diuji. Hal ini dilakukan bertujuan untuk meminimalisir sebuah kesalahan (error) dan memastikan ouput yang dihasilkan sesuai dengan yang diharapkan (Lutfi, 2017).

\section{e. Support}

Tidak menutup kemungkinan juga sebuah perangkat lunak yag mengalami perubahan ketika sudah dikirim ke sebuah user. Perubahan biasa terjadi karena, adanya kesalahan yang telah muncul dan tidak terdeteksi saat pengujian diakukan atau perangkat lunak harus beradaptasi dengan pendataan baru, tahap pendukung atau pemiliharaan dapat mengulangi suatu proses pengembangan yang di mulai dari analisa spesifikasi untuk perubahan perangkat lunak yang telah ada.

\section{HASIL DAN PEMBAHASAN}

\section{Activity Diagram}

Dalam diagram activity ini menjelaskan alur bagaimana suatu pekerjaan dilakukan antara pihak perusahaan dengan pihak yang terlibat dalam sebuah pekerjaan. Activity diagram merupakan alur kerja atau kegiatan dari sebuah sistem atau menu yang ada pada perangkat lunak. Berikut ini merupakan activity diagram sistem berjalan pada CV. Berkah Jaya dapat dilihat pada Gambar 1 dan Gambar 2:

a. Activity Diagram sistem berjalan pemasukan dana keuangan

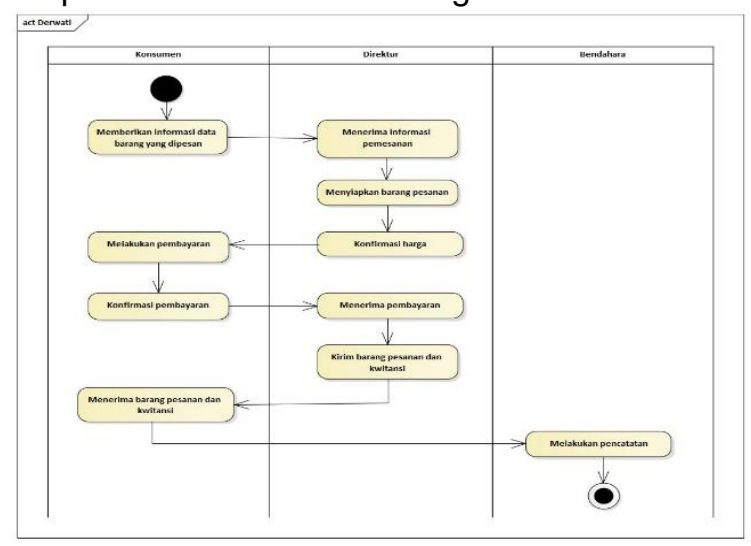

Sumber: Hasil dari Penelitian (2020)

Gambar 1. Activity Diagram Sistem Bisnis Berjalan Pemasukan Dana Keuangan

b. Activity diagram sistem berjalan pengeluaran dana keuangan

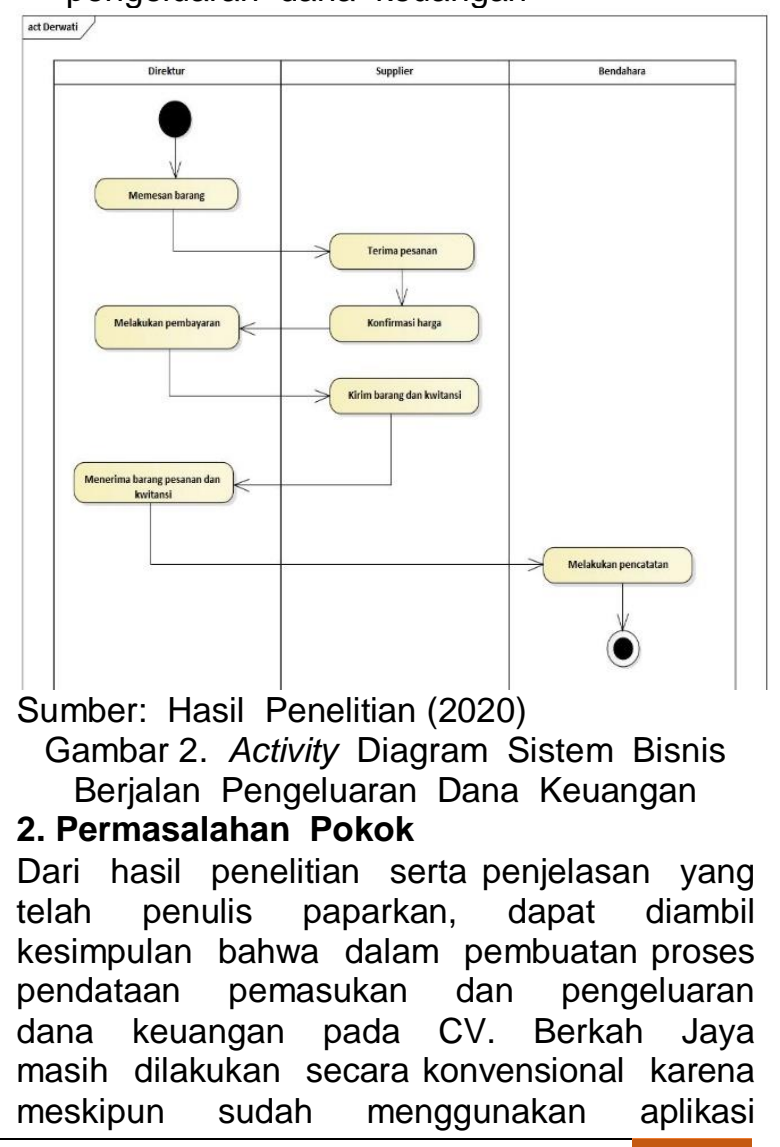


microsoft excel, tetapi masih terdapat kekurangan terutama dalam hal laporan tersebut masih sering di cetak untuk diperlihatkan atau pada saat kepada direktur meminta laporan tersebut dan seringkali data lama juga hilang ataupun lupa tempat menyimpan file data tersebut. Dengan proses yang dilakukan pihak perusahaan dalam merekapitulasikan data dalam transaksi yang masih dengan cara yang sudah penulis jelaskan, hal ini menjadi tidak efektif dan efisien untuk perusahaan CV. Berkah Jaya, sehingga dapat menghambat dan memperlambat dalam proses transaksi, serta membutuhkan waktu yang lama dalam pencarian data, membuang banyak kertas untuk pengecekan data, dan membuat laporan yang diperlukan.

\section{Pemecahan Masalah}

Untuk memecahkan masalah yang ada di CV. BERKAH JAYA, khususnya pada bagian pencatatan data transaksi, hendaknya pihak perusahaan $\mathrm{CV}$. BERKAH JAYA menggunakan sistem yang telah terkomputerisasi dalam sebuah aplikasi tersendiri sehingga permasalahan diatas dapat teratasi. Selain itu meningkatkan dan mempermudah dalam proses pencatatan pemasukan dan pengeluaran dana keuangan, meminimalisasi kesalahan pencatatan, mengurangi resiko kerusakan pada data transaksi, dan mengurangi penggunaan kertas.

\section{Analisa Kebutuhan Software}

Analisis kebutuhan software merupakan langkah awal untuk menentukan gambaran perangkat yang akan dihasilkan ketika pengembang melaksanakan sebuah proyek pembuatan perangkat lunak. Analisis kebutuhan ini mempunyai fungsi menjabarkan semua kebutuhan sistem yang ada berkaitan dengan kebutuhan sistem yang dibutuhkan oleh pengguna itu sendiri, dan ini harus benar-benar bisa dipenuhi sistem yang ada untuk penggunanya.

\section{Analisa Kebutuhan Fungsional}

Analisa kebutuhan fungsional yang dirancang berdasarkan hasil penelitian memiliki beberapa hak akses yang berguna untuk menjalankan aplikasi sistem tersebut. Dalam penggunaannya setiap level akses ini mempunyai cara interaksi tersendiri didalam sebuah sistem yang ada dan juga mereka memiliki kebutuhan sistem yang berbeda juga terhadap sistem yang ada seperti berikut:

A. Admin

A.1. Admin Login

A.2. Admin Mengelola Data User

A.3. Admin Mengelola Data Master

A.4. Admin Mengelola Data Transaksi

\section{A.5. Admin Mengelola Data Laporan}

B. Bendahara

B.1. Bendahara Login

B.2. Bendahara Mengelola Data Master

B.3. Bendahara Mengelola Data Transaksi

B.4. Bendahara Mengelola Data Laporan

C. Direktur

C.1. Direktur Login

C.2. Direktur Melihat Data Master

C.3. Direktur Melihat Data Laporan

\section{Desain}

A. Entity Relationship Diagram (ERD) Entity Relationship Diagram (ERD) merupakan suatu pemodelan dari kelompok basis data relasional yang didasari dari atas persepsi yang ada didalam dunia nyata, dunia ini sejatinya terdiri dari bebrapa kumpulan objek yang saling terhubung antara satu dengan yang lain. Suatu objek yang disebut entity dan hubungan yang dimilikinya disebut sebagai relationship, menjadi mentalist Suatu entity bersifat unik dan memiliki atribut sebagai pembeda dengan entity lainnya(Eka Wida Fridayanthie1, 2016).

\section{B. Logical Record Structure (LRS)}

Logical Record Structure (LRS) adalah representasi dari struktur record-record yang terdapat pada tabel-tabel yang terbentuk dari hasil antar himpunan entitas yang akan digunakan unuk menentukan kardinalitas, jumlah tabel dan Foreign Key (FK) seperti ditunjukkan dalam gambar 3 .

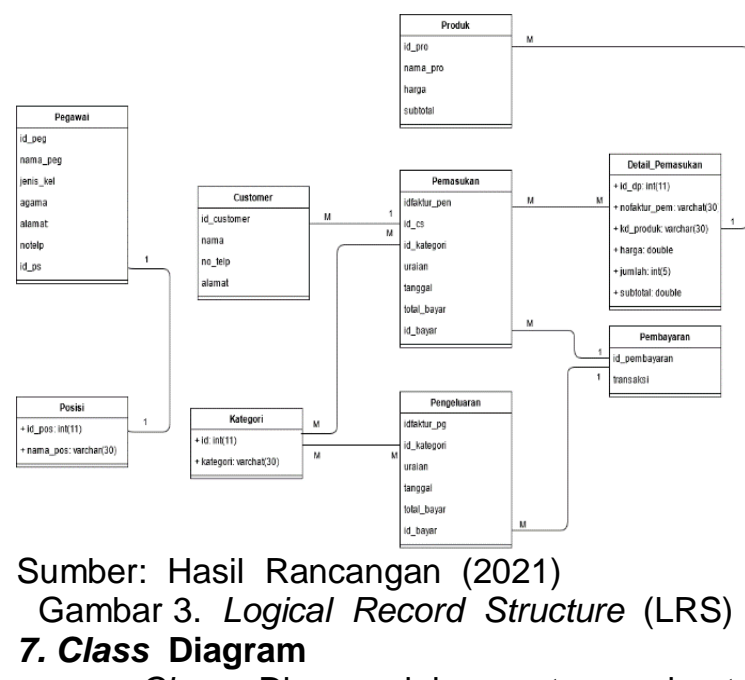

Class Diagram ini sangat membantu dalam proses visualisasi kelas dari sebuah sistem, hal ini disebabkan karena class diagram merupakan deskripsi kelompok objek-objek dengan atribut (property), perilaku (operation), dan relasi yang sama. Gambar 4 menunjukkan gambaran mengenai sistem dan relasi-relasi didalamnya dalam bentuk class diagram yang dirancang pada Gambar 4: 


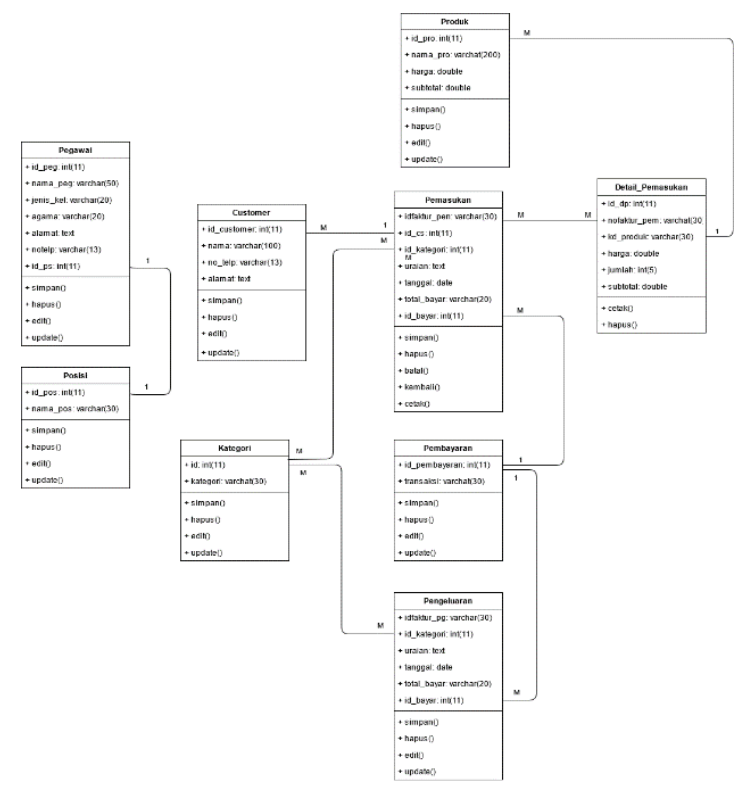

Sumber: Hasil Rancangan (2021)

Gambar 4. Class Diagram

\section{Sequence Diagram}

Sequence diagram daam penelitian digunakan untuk menggambarkan sebuah interaksi antar objek dalam waktu yang berurutan. Tetapi pada dasarnya sequence diagram digunakan dalam lapisan abstraksi model objek(Larasati \& Masripah, 2017).

\section{Deployment Diagram}

Diagram Deployment ini merupakan salah satu diagram yang paling penting dalam tingkat implementasi. Deployment diagram yang digunakan untuk memetakan software ke processing node. Menunjukan konfigurasi elemen pemproses pada saat run time dan software yang ada di dalamnya.

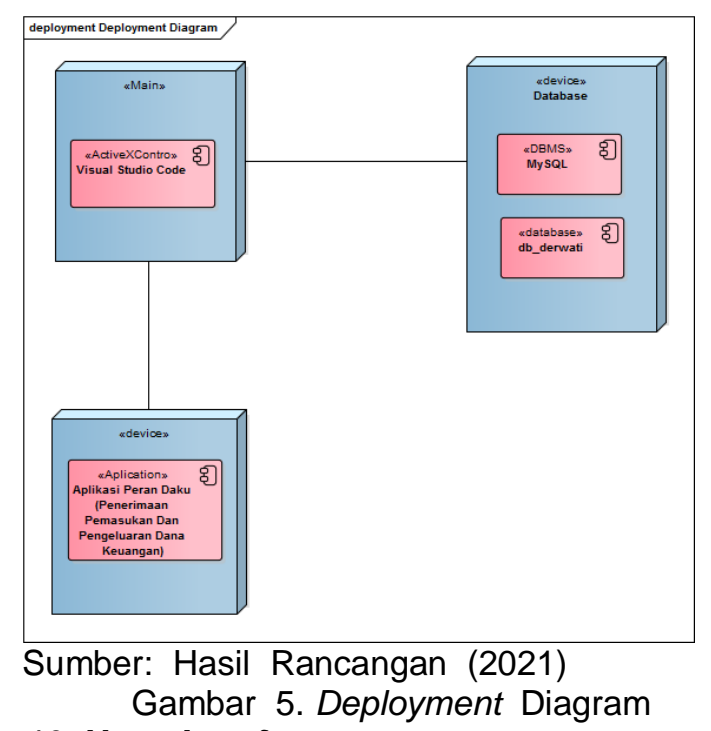

\section{User Interface}

User interface merupakan rancangan antarmuka yang akan berhubungan langsung dengan pengguna perangkat lunak yang dibangun. Uji coba dilakukan dengan localhost dengan bantuan software XAMPP. Tahap ini dilakukan untuk menguji kelayakan dan fungsionalitas dari sistem yang telah dibuat dan diuji dari kebutuhan pengguna(Nur Majdina Hibatur Rahman \& Sri Muryani, 2017).

a. Form login

Pengguna dapat menggunakan setelah melakukan login

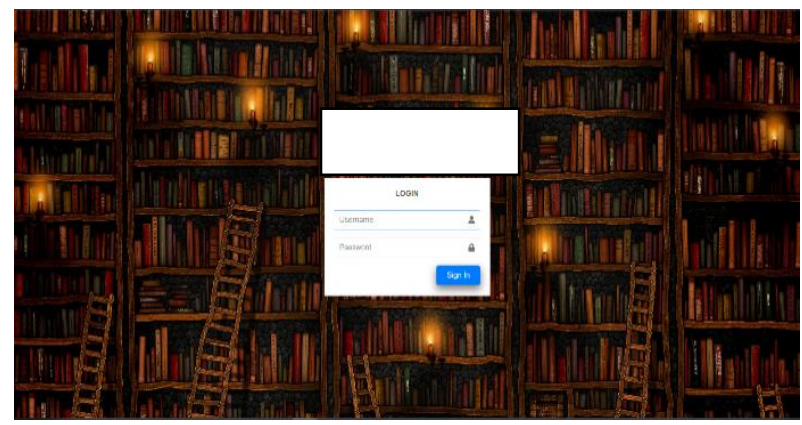

Sumber: Hasil Rancangan (2021)

\section{b. Form Dashboard}

\section{Gambar 6. Form Login}

Halaman ini menampilkan daftar menu yang dapat digunakan ke dalam sistem.

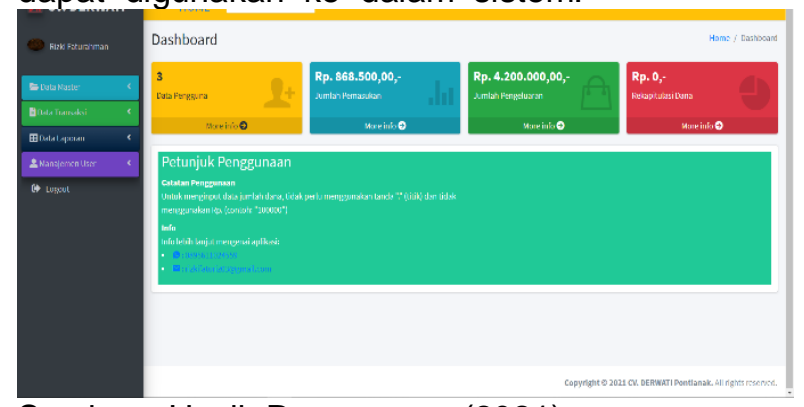

Sumber: Hasil Rancangan (2021)

Gambar 7. Form Dashboard

\section{c. Form Data Master}

Pada menu ini terdapat beberapa sub-menu tentang data master dan akan menampilkan masing-masing isi dari sub-menu tersebut ketika di klik.

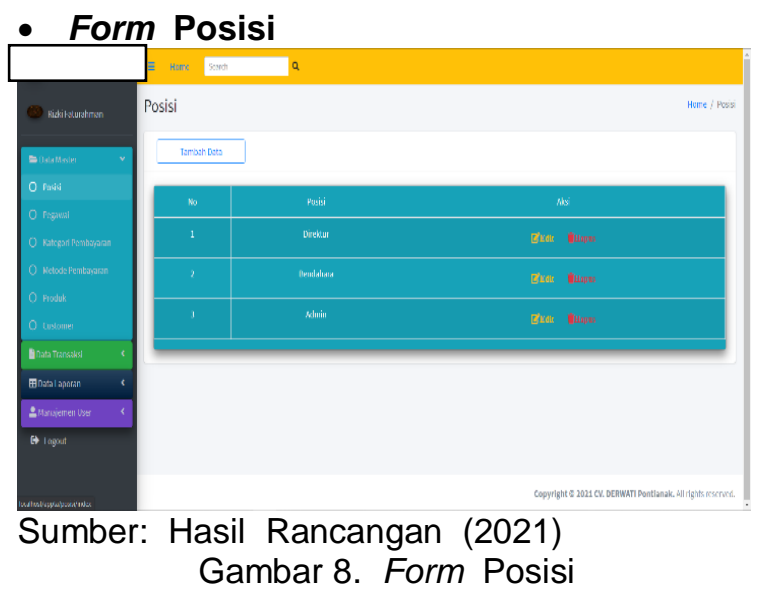

\section{Implementasi}

Dalam tahap implementasi ini penguji menyajikan beberapa alur pengerjaan aplikasi yang terdapat kode program, testing 
untuk pengecekan error atau bug yang terjadi pada sistem, dan spesifikasi hardware dan software yang diusulkan sebagai syarat untuk menjalankan program yang telah diusulkan.

\section{Blackbox Testing}

Pengujian fungsional men-cakup pengecekan tombol dan proses sistem apakah sudah berjalan sesuai dengan kebutuhan atau tidak. Hasil pengujian fungsional ditunjukkan pada pengujian blackbox testing dibawah ini.

Tabel 1.

Hasil Pengujian Blackbox Testing Laporan

\begin{tabular}{|c|c|c|c|c|c|}
\hline No & $\begin{array}{c}\text { Skenaria } \\
\text { Pengujian }\end{array}$ & Test case & $\begin{array}{l}\text { Hasil yang } \\
\text { diharapkan }\end{array}$ & $\begin{array}{c}\text { Hasil } \\
\text { Penguiian }\end{array}$ & Kesimpulan \\
\hline 1 & $\begin{array}{l}\text { Lihat data } \\
\text { laporan } \\
\text { pemasukan } \\
\text { berdasarkan } \\
\text { bulan. }\end{array}$ & $\begin{array}{ll}\text { Tentukan Filter } \\
\text { Laporan bulan } \\
\text { mulai dan } \\
\text { sampai dan } \\
\text { klik } \\
\text { klik cetak } \\
\text { periede } & \\
\end{array}$ & $\begin{array}{l}\text { Sistem } \\
\text { meneerima dan } \\
\text { meanamilkan } \\
\text { data laporan } \\
\text { pemasukukan, } \\
\text { klik print yntuk } \\
\text { mencetak } \\
\text { laporan, } \\
\text { laporan } \\
\text { berbasil di } \\
\text { cetak }\end{array}$ & $\begin{array}{l}\text { Sesuai } \\
\text { harapan }\end{array}$ & $\begin{array}{l}\text { Valid } \\
\end{array}$ \\
\hline 2 & $\begin{array}{l}\text { Lihat semua } \\
\text { data laporan } \\
\text { pemasukan. }\end{array}$ & $\begin{array}{lr}\text { Tidak } & \text { perlu } \\
\text { filter } & \text { tanggal } \\
\text { klik } & \text { cetala } \\
\text { semua } & \end{array}$ & $\begin{array}{l}\text { Sistem } \\
\text { meneerima dan } \\
\text { menampilkan } \\
\text { data laperan } \\
\text { pemasukukan } \\
\text { klik print yntuk } \\
\text { mencetak } \\
\text { laporan, } \\
\text { laperan } \\
\text { berbasil di } \\
\text { cetak }\end{array}$ & $\begin{array}{l}\text { Sesuai } \\
\text { harapan }\end{array}$ & Valid \\
\hline
\end{tabular}

Tabel 2.

Hasil Pengujian Blackbox Testing Laporan Pengeluaran

\begin{tabular}{|c|c|c|c|c|c|}
\hline No & $\begin{array}{l}\text { Skenaria } \\
\text { Pengujian }\end{array}$ & Test case & $\begin{array}{l}\text { Hasil yang } \\
\text { diharapkan }\end{array}$ & $\begin{array}{c}\text { Hasil } \\
\text { Pengujian }\end{array}$ & Kesimpulan \\
\hline 1 & $\begin{array}{l}\text { Lihat data } \\
\text { lappran } \\
\text { pengeluaran } \\
\text { berdasarkan } \\
\text { bulan }\end{array}$ & $\begin{array}{lr}\text { Tentukan Filter } \\
\text { Laparan bulan } \\
\text { mullai dan sampai } \\
\text { dan blikk [Cetalk } \\
\text { Perioded }\end{array}$ & $\begin{array}{l}\text { Sistem menerima } \\
\text { dan menampilksan } \\
\text { data lapesan } \\
\text { pengeluaran, blikk } \\
\text { print yntuk } \\
\text { mencetakt laporan, } \\
\text { laporan berbasil di } \\
\text { cetak }\end{array}$ & $\begin{array}{l}\text { Sesuai } \\
\text { harapan }\end{array}$ & $\begin{array}{l}\text { Valid } \\
\end{array}$ \\
\hline 2 & $\begin{array}{l}\text { Lihat semua } \\
\text { data laporan } \\
\text { pengeluaram }\end{array}$ & $\begin{array}{l}\text { Tidak perlu filter } \\
\text { tanggal, klik } \\
\text { [Cetak Semua] }\end{array}$ & $\begin{array}{l}\text { Sistem menerima } \\
\text { dan menampilkan } \\
\text { data laporan } \\
\text { pengeluaran. blik } \\
\text { print yntuk } \\
\text { mencetak laporan, } \\
\text { laporan berbasil di } \\
\text { cetak }\end{array}$ & $\begin{array}{l}\text { Sesuai } \\
\text { harapan }\end{array}$ & Valid \\
\hline
\end{tabular}

\section{KESIMPULAN}

Setelah melihat permasalahan sistem pencatatan pemasukan dan pengeluaran dana kas pada CV. BERKAH JAYA penulis mengambil kesimpulan bahwa:

1. Data pemasukan dan pengeluaran dan keuangan akan mudah dimanipulasi oleh pihak yang tidak bertanggung jawab jika masih mengunakan sistem pencatatan yang manual.

2. Dengan adanya system terkomputerisasi, mempermudah perusahaan dalam melakuan proses pengolahan data.

3. Pengolahan data transaksi yang terkomputerisasi dapat menghemat waktu yang diperlukan untuk membuat laporan, seperti laporan data transaksi dan laporan rekapitulasi transaksi.

\section{REFERENS}

Akuntansi, J., \& Ekonomi, F. (2016). Analisis Sistem Akuntansi Penerimaan Dan Pengeluaran Kas Pada Pt. Hasjrat Abadi Manado. Jurnal Berkala IImiah Efisiensi, 16(4), 1087-1097. https://ejournal.unsrat.ac.id/index.php/jbie/ article/view/14197/13771

Apriliah, W. (2019). RANCANG BANGUN SISTEM INFORMASI PENERIMAAN DAN PENGELUARAN KAS PADA PT. RHADOGEL GUMS INTERNASIONAL BEKASI. Jurnal Inkofar, 1(2), 28-39. https://doi.org/10.46846/jurnalinkofar.v1i2. 66

Danial, M., Tinggi, S., \& Ekonomi, I. (2019). PERANAN SISTEM PENGENDALIAN INTERN PENERIMAAN DAN DAN PENGELUARAN KAS DALAM MENUNJANG KEAMANAN DAN AKURASI PENGELOLAAN KAS PT XRITEL

Eka Wida Fridayanthie1, T. M. (2016). RANCANG BANGUN SISTEM INFORMASI PERMINTAAN ATK BERBASIS INTRANET (STUDI KASUS: KEJAKSAAN NEGERI RANGKAS BITUNG). Jurnal Informatika, IV, 2. https://doi.org/https://doi.org/10.31294/jki.v 4i2.1264.g1029

Larasati, H., \& Masripah, S. (2017). Analisa Dan Perancangan Sistem Informasi Pembelian GRC Dengan Metode Waterfall. Jurnal Pilar Nusa Mandiri, 13(2), 193-198.

http://ejournal.nusamandiri.ac.id/index.php /pilar/article/view/237

Lisnawanty, L., \& Kurniawan, B. (2019). Sistem Informasi Akuntansi Penerimaan Dan Pengeluaran Kas Berbasis Web (Studi Kasus: Pt. Sinar Kapuas Cemerlang). Jurnal Riset Informatika, 1(4), 187-196. https://doi.org/10.34288/jri.v1i4.101

Lutfi, A. (2017). Sistem Informasi Akademik Madrasah Aliyah Salafiyah Syafi'lyah Menggunakan Php Dan Mysq. AiTech, 3(2), 104-112. https://www.ejournal.amiki.ac.id/index.php /Aitech/article/view/51

Ningtiyas, J. D. A. (2017). Penyusunan Laporan Keuangan UMKM Berdasarkan Standar Akuntansi Keuangan Entitas Mikro, Kecil dan Menengah (SAK-EMKM) (Study Kasus Di UMKM Bintang Malam Pekalongan). Riset \& Jurnal Akuntansi, 2(1), 11-17. https://owner.polgan.ac.id/index.php/owne r/article/view/28

Nur Majdina Hibatur Rahman, \& Sri Muryani. (2017). Aplikasi Akuntansi Untuk 
Menyusun Laporan Keuangan Pada

Koperasi Amanah Jakarta. Information

Management for Educators and

Professionals, Vol.1, No.(2), 155-168.

http://ejournal-

binainsani.ac.id/index.php/IMBI/article/vie w/409

simatupang julianto, sianturi setiawan. (2019).
PERANCANGAN SISTEM INFORMASI PEMESANAN TIKET BUS PADA PO. HANDOYO BERBASIS ONLINE Julianto. Simatupang, Julianto Sianturi, Setiawan, 3(2),

11-25.

https://journal.amikmahaputra.ac.id/index. php/JIT/article/view/56/48 